\title{
Efektivitas Penggunaan Model Pembelajaran Creative Problem Solving Dengan Metode Drill Untuk Meningkatkan Kemampuan Menyimak Dialog Interaktif Dalam Pembelajaran Bahasa Indonesia
}

\author{
Nyoman Suparmi ${ }^{1}$
}

${ }^{1}$ SMP Negeri 3 Sawan, Buleleng, Indonesia

\author{
A R T I C L E I N F O \\ Article history: \\ Received 31 Oktober 2018 \\ Accepted 30 November 2018 \\ Available online 31 \\ Desember 2018 \\ Kata Kunci: \\ Model Pembelajaran; \\ Creative Problem Solving; \\ Metode Drill; Menyimak \\ Dialog Interaktif; Bahasa \\ Indonesia \\ Keywords: \\ Learning model; Creative \\ Problem Solving; Drill \\ Method; Listening to \\ Interactive Dialogue; \\ Indonesian Language
}

\begin{abstract}
A B S T R A K
Sebagian besar siswa di kelas IXA1 SMP Negeri 3 Sawan belum mencapai tingkat ketuntasan belajar yang ditetapkan di sekolah ini yaitu 75. Dari kekurangan yang ada di lapangan tersebut, peneliti mengupayakan sebuah kajian ilmiah dengan melakukan penelitian tidnakan kelas. Tujuan penelitian yang dilakukan ini adalah untuk mengetahui apakah penerapan model pembelajaran Creative Problem Solving dengan Metode Drill mampu meningkatkan kemampuan siswa dalam menyimak dialog interaktif dalam pembelajaran Bahasa Indonesia. Penelitian yang dilakukan dalam dua siklus menggunakan tahapan perencanaan, pelaksanaan, observasi/pengamatan dan refleksi pada setiap siklusnya memfokuskan pencairan datanya menggunakan tes prestasi belajar dan melaksanakan analisis dengan analisis deskriptif. Setelah dilakukan refleksi, terjadi peningkatan hasil bel;ajar siswa dari rata-rata nilai 71,50 meningkat menjadi 78,86 rata-rata kelasnya pada siklus I dan pada siklus II meningkat menjadi 80,54. Data tersebut menunjukkan keberhasilan pelaksanaan penelitian sesuai indikator yang dicanangkan. Akhirnya peneliti berkesimpulan bahwa penerapan model pembelajaran Creative Problem Solving dengan Metode Drill dapat meningkatkan prestasi belajar siswa dalam menyimak dialog interaktif pada pembelajaran Bahasa Indonesia.
\end{abstract}

\section{A B S T R A C T}

The majority of students in class IXA1 of SMP Negeri 3 Sawan have not reached the level of learning completeness established in this school which is 75. Of the shortcomings in the field, researchers are seeking a scientific study by conducting classroom study. The purpose of this study was to determine whether the application of the Creative Problem Solving learning model with the Drill Method was able to improve students' ability to listen to interactive dialogues in Indonesian learning. Research conducted in two cycles using the stages of planning, implementation, observation/reflection and reflection in each period focuses on disbursing the data using learning achievement tests and carrying out an analysis with descriptive analysis. After reflection, there was an increase in bell results, teaching students from an average value of 71.50 increased to 78.86 in the average class in the first cycle and in the second cycle increased to 80.54. This data shows the success of the implementation of the research according to the proclaimed indicators. Finally, the researchers concluded that the application of the Creative Problem Solving learning model with the Drill Method could improve student learning achievement in listening to interactive dialogue on Indonesian learning.

Copyright (C) Universitas Pendidikan Ganesha. All rights reserved.

\footnotetext{
Corresponding author.

E-mail addresses: nyoman.suparmi1964@gmail.com
} 



\section{Pendahuluan}

SMP Negeri 3 Sawan yang merupakan salah satu lembaga pendidikan yang ada di kecamatan Sawan utamanya dalam pembelajaran mengalami beberapa kendala, khususnya dalam pelaksanaan pembelajaran Bahasa Indonesia di kelas XA1. Masalah pembelajaran ini adalah tentang ketidakmampuan peserta didik menempa ilmu sesuai harapan. Nilai rata-rata kelas ini baru diperoleh 71,50 dengan ketuntasan 23 orang $(82,14 \%)$ dari 28 orang peserta didik serta 5 orang siswa $(17,86 \%)$ belum mencapai ketuntasan. Tentunya hal ini masih jauh dari KKM yaitu 76.

Yang diharapkan dipihak guru, sekolah agar guru lebih giat dalam membuat perencanaan. H. Martinis Yamin dan Jamilah Sabri Sanan (2013) menjelaskan bahwa guru sebagai tenaga profesional bertugas merencanakan, melaksanakan, menilai, membimbing, melatih, melakukan penelitian, memenuhi standar kompetensi. Guru wajib menciptakan suasana pendidikan yang bermakna, menyenangkan, kreatif, dinamis, dialogis, berkomitmen meningkatkan mutu pendidikan, memberi tauladan, menjaga nama baik lembaga. Guru berperan untuk mampu melakukan interaksi, pengasuhan, mengatur tekanan, memberi fasilitas, perencanaan, pengayaan, menanganai masalah, membimbing dan memelihara. Apabila guru memahami tugas-tugas tersebut dan memahami apa yang mesti dilakukan tentu saja kondisi yang diharapkan dalam pembelajaran di sekolah akan dapat terlaksana dengan baik.

Pendapat di atas berisi harapan-harapan dipihak guru agar mampu melaksanakan proses pembelajaran yang baik dan benar. Untuk dapat melakukan hal tersbeut, sebagai seorang guru harus paham dengan faktor-faktor yang mempengaruhi pertumbuhan dan perkembangan anak. Faktor-faktor yang mempengaruhi pertumbuhan dan perkembangan anak menurut Ari Sulistiyo (2011) menyatakan : 1) faktor internal, faktor yang bersumber dari dalam diri seperti genetik dan proses selama kehamilan; 2) faktor eksternal yaitu faktor-faktor luar seperti gizi, penyakit, aktivitas fisik, keluarga, lingkungan.

Guru harus mampu memilih dan menggunakan metode, strategi, pendekatan, model serta teknik yang tepat dalam melaksanakan pembelajaran sehingga kondisi pembelajaran yang diharapkan dapat berjalan sesuai keinginan. Yuliani Nurani Sujiono (2009) menjelaskan bahwa guru yang baik memiliki banyak sifat dan ciri khas, yaitu: kehangatan hati, kepekaan, mudah beradaptasi, jujur, ketulusan hati, sifat yang bersahaja, sifat yang menghibur, menerima perbedaan individu, mampu mendukung pertumbuhan tanpa terlalu melindungi, badan yang sehat dan kuat, ketegaran hidup, perasaan kasihan/keharuan, menerima diri, emosi yang stabil, percaya diri, mampu untuk terus menerus berpartisipasi dan dapat belajar dari pengalaman.

Semua kutipan di atas menunjukkan serta menjelaskan semua harapan di pihak guru dalam melaksanakan proses pembelajaran. Guru harus mampu melaksanakannya dengan sebaik-baiknya agar peningkatan mutu pendidikan dapat dicapai sesuai harapan. Kenyataan yang ada di lapangan ternyata tidak sesuai dengan semua harapan tadi, ini terlihat pada data awal penilaian yang dilakukan di kelas XA1 tahun pelajaran 2017/2018 semester 1 dalam pembelajaran Bahasa Indonesia baru mencapai rata-rata 71,50 dengan ketuntasan belajar baru mencapai $82,14 \%$

Tidak sinkronnya antara kondisi yang diharapkan dengan kondisi nyata yang ada di lapangan memunculkan kesenjangan akibat ketidakmampuan guru, kurangnya media pendukung serta kebiasaan peserta didik yang lebih senang bersantai dari pada belajar. Hal ini membuat peneliti harus bekerja keras untuk memecahkan masalah yang ada. Untuk hal tersebut peneliti mencoba penggunana model pembelajaran Creative Problem Solving untuk dapat mengupayakan peningkatan prestasi belajar peserta didik.

Model Creative Problem Solving (CPS) pertama kali dikembangkan oleh Alex Osborn pendiri The Creative Education Foundation (CEF) dan co-founder of highly successful New York Advertising Agenncy. Pada tahun 1950-an Sidney Parnes bekerjasama dengan Alex Osborn melakukan penelitian untuk menyempurnakan model ini. Sehingga model Creative Problem Solving ini juga dikenal dengan nama The Osborn-parnes Creative Problem Solving Models. Pada awalnya model ini digunakan oleh perusahaan-perusahaan dengan tujuan agar para karyawan memiliki kreativitas yang tinggi dalam setiap tanggungjawab pekerjaannya, namun pada perkembangan selanjutnya model ini juga diterapkan pada dunia pendidikan. 
Model CPS adalah suatu model pembelajaran yang melakukan pemusatan pada pengajaran dan keterampilan pemecahan masalah, yang diikuti dengan penguatan keterampilan. Ketika dihadapkan dengan suatu pertanyaan, siswa dapat melakukan keterampilan memecahkan masalah untuk memilih dan mengembangkan tanggapannya. Tidak hanya dengan cara menghafal tanpa dipikir, keterampilan memecahkan masalah memperluas proses berpikir (Pepkin, 2004). Adapun proses dari model pembelajaran CPS (Creative Problem Solving), terdiri atas klarifikasi masalah, pengungkapan pendapat, evaluasi dan pemilihan, dan implementasi. Dengan membiasakan siswa menggunakan langkah-langkah yang kreatif dalam memecahkan masalah, diharapkan dapat membantu siswa untuk mengatasi kesulitan dalam belajar. Penggunaan model pembelajaran CPS ini diharapkan dapat menimbulkan minat sekaligus kreativitas dan motivasi siswa dalam mempelajari setiap materi pelajaran, sehingga siswa dapat memperoleh manfaat yang maksimal baik dari proses maupun prestasi belajarnya (Supardi dan Putri, 2010).

Cholis (2002) dalam Dyah Retno Kusuma Wardani (2011) menyebutkan ada beberapa hal yang perlu diperhatikan dalam pembelajaran pemecahan masalah yakni: 1) menentukan permasalahan yang akan disajikan disesuikan dengan materi, 2) masalah yang disajikan harus mampu mendorong siswa berpikir dari berbagai sudut pandang yang berbeda, 3) masalah harus disesuaikan dengan dengan tingkat kemampuan siswa, 4) masalah harus jelas, 5) masalah dikaitkan dengan dunia nyata dan cukup menarik siswa.

Cara yang digunakan dalam memecahkan masalah yang ada dalam penelitian ini adalah dengan menggunakan cara Creative Problem Solving yaitu guru giat secara kreatif mengupayakan cara pemecahan pada saat peserta didik mengalami masalah. Selanjutnya dilakukan drill atau latihan yang diulang-ulang yang dianggap sulit bagi siswa. Dalam buku Nana Sudjana (1991), metode drill adalah suatu kegiatan melakukan hal yang sama, berulang-ulang secara sungguh-sungguh dengan tujuan untuk memperkuat suatu asosiasi atau menyempurnakan suatu keterampilan agar menjadi bersifat permanen. Ciri yang khas dari metode ini adalah kegiatan berupa pengulangan yang berkali-kali dari suatu hal yang sama. Menurut Asmani (2009) Metode latihan (drill) disebut juga metode training, yaitu suatu cara mengajar untuk menanamkan kebiasaan-kebiasaan tertentu. Selain itu, juga dapat digunakan sebagai sarana untuk memelihara kebiasaan-kebiasaan yang baik. Di samping itu, metode ini dapat digunakan untuk memperoleh suatu ketangkasan, ketepatan, kesempatan, dan keterampilan.

Berdasarkan pendapat tersebut penulis menyimpulkan metode latihan adalah suatu cara mengajar untuk menanamkan kebiasaan-kebiasaan yang baik. Ada keterampilan yang dapat disempurnakan dalam jangka waktu yang pendek dan ada yang membutuhkan waktu cukup lama. Perlu diperhatikan latihan itu tidak diberikan begitu saja kepada siswa tanpa pengertian, jadi latihan itu didahului dengan pengertian dasar. Adapun tujuan kajian ini adalah untuk mengetahui seberapa tinggi peningkatan prestasi belajar siswa akan terjadi setelah diterapkan model pembelajaran Creative Problem Solving dengan metode Drill dalam pembelajaran.

\section{Metode}

Sekolah tempat dilaksanakannya penelitian ini adalah SMP Negeri 3 Sawan khusunya di kelas IXA1. Sekolah ini berada di sebelah timur pusat desa yaitu Desa Suwug Kecamatan Sawan. Penelitian ini merupakan Penelitian Tindakan Kelas (PTK) atau Classroom Action Research (Arikunto, Suhardjono dan Supardi, 2006). PTK memiliki peranan yang sangat penting dan strategis untuk meningkatkan mutu pelajaran melalui suatu tindakan bermakna dengan menggunakan sebuah model atau suatu pendekatan pembelajaran yang diperhitungkan dapat memecahkan masalah atau memperbaiki situasi dan kemudian secara cermat mengamati pelaksanaannya untuk mengukur tingkat keberhasilannya. Alur PTK seperti terlihat pada Gambar 1. Subyek penelitian adalah siswa kelas IX A1 SMP Negeri 3 Sawan yang berjumlah 28 orang siswa. Dalam penelitian ini objek penelitiannya adalah peningkatan prestasi belajar dalam kemampuan menyimak dialog interaktif siswa kelas IXA1 SMP Negeri 3 Sawan semester ganjil tahun pelajaran 2017/2018. Pelaksanaan penelitian ini dijadwalkan dari bulan Juli sampai bulan Oktober 2017 


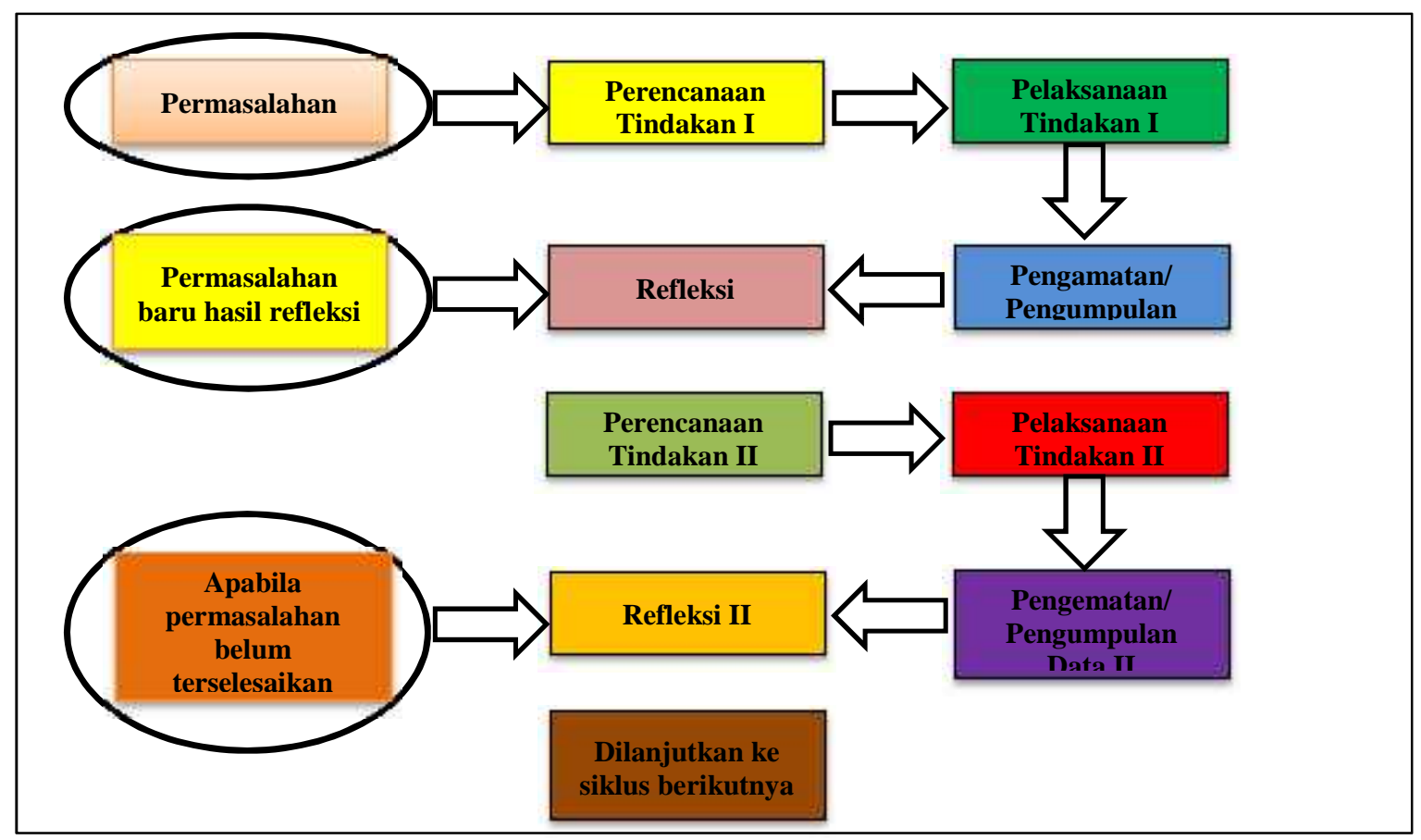

Gambar 1. Alur Penelitian Tindakan Kelas

(dalam Arikunto, Suhardjono, Supardi, 2006)

Instrumen penelitian terlebih dahulu harus dibuatkan kisi-kisi agar arah penelitian menjadi benar. Berikut adalah tabel kisi-kisi instrumen penelitian seperti terlihat pada Tabel 1.

Tabel 1. Kisi-Kisi Tes Prestasi Belajar

\begin{tabular}{|c|c|c|c|c|c|}
\hline No & $\begin{array}{c}\text { Standar } \\
\text { Kompetensi }\end{array}$ & Kompetensi Dasar & Materi & Indikator & Bentuk Tes \\
\hline \multirow[t]{2}{*}{1.} & $\begin{array}{l}\text { 1. Memahami } \\
\text { dialog } \\
\text { interaktif } \\
\text { pada } \\
\text { tayangan } \\
\text { televisi/siara } \\
\text { n radio. }\end{array}$ & $\begin{array}{l}\text { 1.1. Menyimpulkan } \\
\text { dialog interaktif } \\
\text { beberapa } \\
\text { narasumber pada } \\
\text { tayangan } \\
\text { televise/siaran } \\
\text { radio }\end{array}$ & $\begin{array}{l}\text { Dialog } \\
\text { Interaktif }\end{array}$ & $\begin{array}{l}\text { 1. Mampu mencatat pokok- } \\
\text { pokok pernyataan peserta } \\
\text { dialog. } \\
\text { 2. Mampu menentukan hal- } \\
\text { hal penting dalam dialog } \\
\text { yang didengarkan. } \\
\text { 3. Mampu menyimpulkan isi } \\
\text { dialog yang didengarkan } \\
\text { 4. Mampu menilai pernyataan } \\
\text { peserta dialog yang } \\
\text { didengarkan }\end{array}$ & $\begin{array}{l}\text { Tes } \\
\text { Keterampi- } \\
\text { lan } \\
\text { /Perbuatan } \\
\text { /Nontes }\end{array}$ \\
\hline & & $\begin{array}{l}\text { 1.2. Mengomentari } \\
\text { pendapat nara } \\
\text { sumber dalam } \\
\text { dialog interaktif } \\
\text { pada tayanyan } \\
\text { televise/siaran } \\
\text { radio. }\end{array}$ & $\begin{array}{l}\text { Dialog } \\
\text { Interaktif }\end{array}$ & $\begin{array}{l}\text { 1. Mampu mencatat pokok- } \\
\text { pokok pendapat } \\
\text { narasumber dalam dialog } \\
\text { interaktif yang } \\
\text { didengarkan } \\
\text { 2. } \\
\text { Mampu menanggapi } \\
\text { pendapat narasumber } \\
\text { dalam dialog interaktif } \\
\text { yang didengarkan dengan } \\
\text { alasan yang logis. } \\
\text { 3. } \\
\text { Mampu menyimpulkan isi } \\
\text { dialog interaktif yang } \\
\text { didengarkan. }\end{array}$ & $\begin{array}{l}\text { Tes Tulis : } \\
\text { Uraian }\end{array}$ \\
\hline
\end{tabular}


Salah satu alat yang digunakan dalam pelaksanaan penelitian ini adalah tes prestasi belajar. Tes tersebut digunakan sebagai instrumen dalam penelitian ini. Tes ini terlampir di masing-masing RPP pada lampiran. Indikator keberhasilan penelitian yang diusulkan dalam penelitian ini pada siklus I mencapai ketuntasan prestasi belajar sebesar $87 \%$ dan pada siklus II mencapai ketuntasan prestasi belajar minimal 89\%.

\section{Hasil dan pembahasan}

\subsection{Kondisi Pra-Siklus}

Gambaran yang diperoleh dari kegiatan awal adalah di satu pihak tidak berhasilnya guru dalam melaksanakan pembelajaran mengingat kegiatan yang dilakukan belum mengikuti pendapat para ahli pendidikan. Metode yang digunakan masih tradisional, masih yang biasa dilakukan sehari-hari misalnya penggunaan metode tanya jawab masih satu arah atau paling tinggi dua arah, dan belum giat menggunakan metode tanya jawab multiarah. Model yang digunakan masih juga menggunakan model yang bisa dilakukan sehari-hari, belum mengikuti model yang digunakan para ahli pendidikan. Akibatnya nilai siswa masih cukup rendah, hanya 23 orang dari 28 siswa di IXA1 yang mampu memperoleh ketuntasan belajar, sedangkan yang lainnya yaitu 5 orang $(17,86 \%)$ masih berada pada kriteria dibawah KKM. Di lain pihak yaitu di pihak siswa, hal ini merupakan ciri bahwa sebagian besar peserta didik masih membutuhkan bimbingan dan latihan serius untuk dapat meningkatkan perkembangan diri mereka dari kebiasaan sehari-hari yang niat belajarnya rendah.

\subsection{Pembelajaran pada Siklus I}

1) Perencanaan Siklus I

Perencanaan pada Siklus I disusun sedemikian rupa untuk membantu peserta didik dalam meningkatkan prestasi belajar mereka. Adapun persiapan yang direncanakan yaitu :

1) Menyusun rencana kegiatan, menyusun jadwal.

2) Menyusun RPP

3) Berkonsultasi dengan teman-teman guru membicarakan alat-alat peraga, bahan-bahan yang bisa membantu proses pembelajaran.

4) Merencanakan model pembelajaran yang paling tepat dengan menyiapkan media-media yang diperlukan.

5) Menyusun format penilaian.

6) Membuat bahan-bahan pendukung pembelajaran lainnya seperti RPP, silabus dan daftar nilai.

7) Merancang skenario pembelajaran.

2) Pelaksanaan Tindakan Siklus I

1) Pada saat akan memasuki kelas, semua persiapan-persiapan ajar telah dibawa.

2) Memasuki kelas guru memberi salam pada anak-anak.

3) Anak-anak diatur sedemikian rupa agar mendapat ruang yang cukup untuk belajar.

4) Mengelola kelas sambil membimbing mereka dengan memperhatikan kebutuhan setiap anak.

5) Pada saat membimbing, penulis mengisi di daftar nilai bagi anak-anak yang aktif dan bisa menjawab pertanyaan dengan baik.

3) Observasi dan Evalusi Siklus I

Observasi terhadap keberhasilan pelaksanaan proses pembelajaran, disampaikan pada Tabel 1. 
Tabel 1. Data Kelas Interval Siklus I

\begin{tabular}{ccccc}
\hline $\begin{array}{c}\text { No } \\
\text { Urut }\end{array}$ & Interval & $\begin{array}{c}\text { Nilai } \\
\text { Tengah }\end{array}$ & $\begin{array}{c}\text { Frekuensi } \\
\text { Absolut }\end{array}$ & $\begin{array}{c}\text { Frekuensi } \\
\text { Relatif }\end{array}$ \\
\hline 1 & $63-66$ & 64,5 & 2 & 7 \\
2 & $67-70$ & 68,5 & 2 & 7 \\
3 & $71-74$ & 72,5 & 1 & 3 \\
4 & $75-78$ & 76,5 & 3 & 11 \\
5 & $79-82$ & 80,5 & 15 & 54 \\
6 & $83-87$ & 85,0 & 5 & 18 \\
& Total & & 28 & 100 \\
\hline
\end{tabular}

4) Refleksi Siklus I

Refleksi merupakan kajian secara menyeluruh tindakan yang telah dilakukan berdasar data yang telah terkumpul, kemudian dilakukan evaluasi guna penyempurnaan tindakan. Semua ini dilakukan untuk dapat menunjukkan perkembangan siswa yang dapat diamati dari kemajuan-kemajuan yang mereka capai, kekurangan-kekurangan yang ada, keterlambatan gaya berpikir, kemampuan untuk cepat tidaknya dalam mengambil keputusan, kemauan mereka untuk menguasai yang diajar, kemauan berkomunikasi, kemampuan analisis dan lain-lain. Semua data yang telah terkumpul menjadi dasar refleksi tersebut.

Refleksi dari hasil tindakan pada siklus I dapat disampaikan bahwa dari 28 anak yang diteliti, 85,71\%\% anak sudah sesuai harapan indikator dengan mendapat penilaian diatas KKM. Hasil tersebut menunjukkan bahwa anak mampu meningkatkan prestasi belajar mereka dalam mata pelajaran Bahasa Indonesia. Selebihnya yang jumlahnya 14,29\% belum mencapai tingkat keberhasilan sesuai harapan, artinya mereka masih harus lebih giat belajar, guru harus lebih giat membimbing.

Dari data pencapaian siklus I ini dapat diberikan sintesis bahwa pencapaian peningkatan prestasi belajar siswa belum sesuai harapan indikator keberhasilan penelitian yang diusulkan yaitu $87 \%$ atau lebih anak mencapai tingkat keberhasilan sesuai dan melebihi KKM. Penilaian terhadap seluruh kegiatan penelitian yang sudah dilakukan pada Siklus I merupakan hal yang perlu dijelaskan terhadap semua kekurangan-kekurangan dan kelebihan-kelebihan yang ada.

Kekurangan-kekurangan yang ditemukan :

1) Untuk menanamkan konsep metode Drill pada kemampuan menyimak dialog interaktif pada mata pelajaran Bahasa Indonesia secara mendalam pada anak didik dibutuhkan waktu yang lebih lama lagi, sebab sebagian anak belum memiliki dasar-dasar pengetahuan tentang konsep tersebut.

2) Keterampilan siswa dalam melakukan hal-hal yang diminta masih belum terlatih, masih banyak anak yang belum terbiasa melakukan hal tersebut.

Kelebihan yang ada adalah :

1) Alat peraga telah disiapkan dengan baik agar mendukung proses pembelajaran.

2) Pengelolaan kelas sudah diupayakan dan bimbingan terhadap anak juga sudah dilakukan dengan maksimal.

3) Teori-teori yang ada sudah digunakan dalam melaksanakan proses pembelajaran.

Semua kekurangan yang telah disampaikan itu akan dibenahi pada siklus selanjutnya.

Demikian penilaian yang bisa disampaikan untuk memberikan gambaran terhadap keberadaan semua tindakan yang telah dilakukan.

\subsection{Pembelajaran pada Siklus II}

1) Perencanaan Siklus II

Mengacu pada hasil analisis dan penilaian pelaksanaan siklus I, penulis melakukan hal-hal berikut dalam perencanaan :

1) Mencek jadwal yang akan dilakukan di lapangan.

2) Mencek kekurangan-kekurangan sebelumnya seperti gerakan siswa yang benar.

3) Berkonsultasi dengan teman-teman guru tentang kelemahan gerakan. 
4) Menyusun rencana dalam mengatasi masalah yang ada, yaitu masalah kemampuan menyimak yang belum benar diperbaiki dengan cara memberi latihan berulang, dan kekurangan dalam menyimak diupayakan diatasi dengan melatih secara berulang/drill.

5) Menyusun RPP mengikuti alur model pembelajaran Creative Problem Solving.

2) Pelaksanaan Tindakan Siklus II

1) Mengajar dengan membawa semua persiapan-persiapan ajar.

2) Mengatur anak-anak agar duduk dengan rapi dan ada ruang yang cukup bagi anak-anak untuk mengikuti proses dengan baik.

3) Pada saat membimbing, penulis mengisi blanko observasi yang telah dibuat untuk memberi penilaian terhadap siswa-siswa yang efektif dalam belajar.

4) Mengajar dengan cara, pertama, melakukan pembelajaran pendahuluan yaitu dengan memberikan apersepsi yang lebih terarah pada materi, dan kedua, melakukan pembelajaran eksplorasi yaitu : menggali kemampuan siswa untuk menyimak.

3) Observasi dan Evalusi Siklus II

Pada observasi ini peneliti mencari data hasil penelitian dengan memberi nilai pada peserta didik pada saat melaksanakan pembelajaran Bahasa Indonesia yaitu pada keterampilan menyimak dalam dialog interaktif. Hasil penilaiannya disampaikan pada Tabel 2.

Tabel 2. Data Kelas Interval Siklus II

\begin{tabular}{ccccc}
\hline $\begin{array}{c}\text { No } \\
\text { Urut }\end{array}$ & Interval & $\begin{array}{c}\text { Nilai } \\
\text { Tengah }\end{array}$ & $\begin{array}{c}\text { Frekuensi } \\
\text { Absolut }\end{array}$ & $\begin{array}{c}\text { Frekuensi } \\
\text { Relatif }\end{array}$ \\
\hline 1 & $72-74$ & 73,0 & 2 & 7 \\
2 & $75-77$ & 76,0 & 1 & 4 \\
3 & $78-80$ & 79,0 & 10 & 35 \\
4 & $81-83$ & 82,0 & 12 & 43 \\
5 & $84-86$ & 85,0 & 2 & 7 \\
6 & $87-90$ & 88,5 & 1 & 4 \\
& Total & & 28 & 100 \\
\hline
\end{tabular}

\section{4) Refleksi Siklus II}

Peningkatan nilai siswa dari data siklus I yang baru mencapai rata-rata 78,86 dengan ketuntasan belajar 85,71\% sudah mampu ditingkatkan menjadi rata-rata 80,54 dengan ketuntasan belajar 92,86\%. Data tersebut artinya hasil yang diperoleh sudah sesuai dengan harapan. Dari perkembangan tersebut diketahui siswa sudah meningkat prestasi

belajarnya. Dari semua data yang sudah diperoleh tersebut dapat diberikan sintesis lanjutan bahwa semua siswa sudah mampu meningkatkan prestasi belajarnya, proses pembelajaran yang dilakukan guru sudah berhasil, inovasi sudah berjalan baik, bimbingan guru sudah maksimal, arahan yang dilakukannya anak-anak giat belajar juga sudah mampu dilakukan dengan baik. Hal tersebut berarti indikator keberhasilan penelitian pada siswa Kelas IXA1 SMP Negeri 3 Sawan sudah terpenuhi.

Penilaian yang dapat diberikan terhadap pelaksanaan Siklus II ini yaitu pembelajaran menggunakan model pembelajaran Creative Problem Solving telah tuntas dapat dilaksanakan. Semua kekurangan-kekurangan yang ada sudah diperbaiki pada siklus ini, sehingga tidak ada yang masih perlu dipaksakan oleh peneliti bahwa penelitian ini tidak perlu dilanjutkan lagi ke siklus berikutnya.

\subsection{Pembahasan}

Sesudah permasalahan dari pelaksanaan pembelajaran awal telah teridentifikasi. Permasalahan tersebut adalah kegiatan pembelajaran yang dilakukan guru adalah pembelajaran yang tanpa teori. Guru masuk kelas langsung mengajar tanpa persiapan yang matang. RPP yang dibawa ke kelas adalah RPP yang dibuatkan oleh MGMP dan tidak membuat sendiri persiapan. Tidak ada upaya inovasi, untuk memperbaiki proses pembelajaran. Siswa yang pasif tidak diupayakan menjadi aktif, media yang digunakan tidak mendukung proses pembelajaran. Setelah dipahami semua hal tersebut merupakan penyebab rendahnya prestasi belajar hingga 
memperoleh ketuntasan belajar hanya dengan 70\% dan nilai rata-rata kelas baru mencapai 76, barulah disasari untuk bisa membuat pembelajaran yang lebih berkualitas.

Penggunaan model pembelajaran Creative Problem Solving dengan metode Drill dalam pembelajaran Bahasa Indonesia ternyata sangat membantu siswa untuk lebih aktif dalam pembelajaran dan peran guru sebagai fasilitator terlaksana dengan sangat baik. Selain itu, suasana pembelajaran lebih fokus pada pengulangan dan penguasaan materi dengan bantuan teman sehingga tujuan pembelajaran dapat tercapai.

Model pembelajaran ini menunjukkan hasil bahwa intensitas siswa untuk aktivitas belajar bertambah, munculnya motivasi kerjasama antar teman, kreativitas siswa tersalurkan, guru dan siswa sama-sama aktif dan kreatif, belajar lebih bermakna karena proses pembelajaran dapat lebih menyenangkan.

Hasil tes prestasi belajar di siklus I telah menemukan efek utama bahwa pelaksanaan tindakan berpengaruh terhadap prestasi belajar anak. Hal ini sesuai dengan hasil meta analisis metode pembelajaran yang dilakukan oleh Soedomo (dalam Puger, 2004) yang menyatakan bahwa metode pembelajaran yang diterapkan oleh seorang guru berpengaruh terhadap prestasi belajarnya.

Permasalahan yang masih tersisa yang perlu dipecahkan adalah prestasi belajar yang dicapai pada siklus I ini belum memenuhi harapan sesuai dengan tuntutan indikator keberhasilan penelitian yakni $87 \%$ atau lebih ketercapaian untuk ketuntasan secara klasikal. Yang diperoleh adalah ketuntasan $85,71 \%$ dengan rata-rata 78,86 . Oleh karenanya upaya perbaikan lebih lanjut masih perlu diupayakan sehingga penelitian masih harus berlanjut ke siklus berikutnya.

Data yang diperoleh peneliti dari hasil tes prestasi belajar di siklus II menunjukkan bahwa kemampuan anak dalam mengikuti pelajaran sudah baik. Ini terbukti dari rata-rata nilai anak mencapai 80,54 dengan ketuntasan 92,86\%. Hasil ini menunjukkan bahwa pelaksanaan tindakan telah berhasil meningkatkan kemampuan anak menempa ilmu sesuai harapan.

Efek pembuktian tentang kebenaran tindakan yang dilaksanakan telah berhasil ditunjukkan bahwa tindakan yang diterapkan dalam proses pembelajaran berpengaruh secara signifikan terhadap prestasi belajar anak. Model pembelajaran Creative Problem Solving merupakan suatu model pembelajaran yang dilakukan dengan cara memperdayakan kemampuan siswa yang memiliki daya serap yang tinggi. Siswa mampu membelajarkan dirinya sehingga memiliki daya serap yang tinggi. Pembelajaran ini mempunyai kelebihan ganda yaitu siswa yang mendapat bantuan lebih efektif dalam menerima materi sedangkan bagi temanteman yang lain merupakan kesempatan untuk mengembangkan kemampuan diri. Dampak positifnya adalah meningkatkan usaha kognitif, komunikasi, percaya diri, dan mendukung hubungan sosial diantara siswa sehingga prestasi belajar siswa dapat tercapai. Dengan model ini keaktifan positif dalam proses belajar mengajar dan menghasilkan prestasi belajar yang lebih baik. Pasaribu dan Simanjuntak (1983) menyatakan bahwa prestasi belajar adalah isi dan kapasitas seseorang. Maksudnya adalah hasil yang diperoleh seseorang setelah mengikuti pendidikan ataupun pelatihan tertentu. Ini bisa ditentukan dengan memberikan tes pada akhir pendidikan itu. Sejalan dengan pandangan tersebut, Sardiman (1988) menyatakan prestasi belajar sangat vital dalam dunia pendidikan, mengingat prestasi belajar itu dapat berperan sebagai hasil penilaian dan sebagai alat motivasi. Adapun peran sebagai hasil penilaian dan sebagai alat motivasi diuraikan seperti berikut. Dalam pembahasan sebelumnya telah dibicarakan bahwa prestasi belajar adalah hasil penilaian pendidikan tentang kemajuan prestasi siswa setelah melakukan aktivitas belajar. Ini berarti prestasi belajar tidak akan bisa diketahui tanpa dilakukan penilaian atas hasil aktivitas belajar siswa. Fungsi prestasi belajar bukan saja untuk mengetahui sejauhmana kemajuan siswa setelah menyelesaikan suatu aktivitas, tetapi yang lebih penting adalah sebagai alat untuk memotivasi setiap siswa agar lebih giat belajar.

Slamet (2003) menunjukkan bahwa faktor-faktor yang mempengaruhi prestasi belajar banyak jenisnya, tetapi dapat digolongkan menjadi dua golongan saja, yaitu faktor intern dan faktor ekstem. Faktor intern diklasifikasi menjadi tiga faktor yaitu: faktor jasmaniah, faktor psikologis dan faktor kelelahan. Faktor jasmaniah antara lain: kesehatan, cacat tubuh. Faktor psikologis antara lain: intelegensi, perhatian, minat, bakat, motif, kematangan, kesiapan. Faktor 
kelelahan antara lain: kelelahan jasmani dan rohani. Sedangkan faktor ekstern digolongkan menjadi tiga faktor yaitu: faktor keluarga, faktor sekolah, faktor masyarakat. Faktor keluarga antara lain: cara orang tua mendidik, relasi antara keluarga, suasana rumah tangga dan keadaan ekonomi keluarga. Faktor sekolah antara lain: metode mengajar, kurikulum, relasi guru dengan siswa, relasi siswa dengan siswa, disiplin sekolah, pelajaran dan waktu sekolah, standar pelajaran, keadaan gedung, metode belajar dan tugas rumah. Faktor masyarakat antara lain: kegiatan siswa dalam masyarakat, mass media, teman bergaul, bentuk kehidupan masyarakat. Peningkatan prestasi belajar yang penulis teliti dalam hal ini dipengaruhi oleh faktor ekstern yaitu metode mengajar guru.

Proses yang dilakukan dalam pembelajaran dengan model pembelajaran Creative Problem Solving lebih mengkaji aspek kognitif, afektif dan psikomotor sebagai pedoman atas kemampuan anak baik pikiran, prilaku maupun keterampilan yang dimiliki. Perbandingan nilai awal, nilai siklus I dan nilai siklus II, menunjukkan terjadinya kenaikan prestasi yang signifikan, yaitu dari rata-rata nilai awal adalah 76,00 naik di siklus I menjadi 78,86 dan di siklus II naik menjadi 80,54. Kenaikan ini menunjukkan upaya maksimal yang dilaksanakan peneliti demi peningkatan kualitas pembelajaran dan mutu pendidikan pendidikan khususnya di Kelas IXA1 SMP Negeri 3 Sawan.

\section{Simpulan dan saran}

Berdasarkan hasil analisis data yang telah dilakukan dengan mengacu pada data yang dikumpulkan dari rumusan masalah, tujuan penelitian, hipotesis tindakan maka dapat ditarik kesimpulan sebagai berikut. Pertama, adapun pembahasan dalam penelitian ini adalah untuk membuktikan apakah model pembelajaran Creative Problem Solving dapat meningkatkan prestasi belajar kemampuan menyimak dalam dialog interaktif pada pembelajaran Bahasa Indonesia siswa kelas IXA1 SMP Negeri 3 Sawan. Dari data awal yang rata-rata baru mencapai 76,00 masih pada katagori cukup dan pada siklus I sudah dapat ditingkatkan menjadi 78,86 dan pada siklus II sudah mencapai 80,54. Selanjutnya, fakta-fakta di atas yang dibarengi dengan penyajian dan hasil observasi di siklus I dan siklus II telah dapat dibuktikan bahwa model pembelajaran Creative Problem Solving dapat meningkatkan kemampuan menyimak dalam dialog interaktif pada pembelajaran Bahasa Indonesia siswa kelas IXA1 SMP Negeri 3 Sawan semester ganjil tahun pelajaran 2017/2018. belajar.

Dari hasil penelitian yang sudah disimpulkan dalam upaya mencapai tujuan pembelajaran, maka dapat disampaikan saran sebagai berikut. Pertama, bagi guru Bahasa Indonesia, apabila mau melaksanakan proses pembelajaran, penggunaan model pembelajaran Creative Problem Solving semestinya menjadi pilihan. Selanjutnya, bagi peneliti lain, walaupun penelitian ini sudah dapat membuktikan bahwa model pembelajaran Creative Problem Solving dapat meningkatkan prestasi belajar siswa, disarankan juga kepada peneliti lain untuk melakukan penelitian lanjutan guna verifikasi data hasil penelitian ini.

\section{Daftar Rujukan}

Arikunto, S., Suhardjono dan Supardi. 2006. Penelitian Tindakan Kelas. Jakarta: PT Bumi Aksara. Asmani, J. M. 2009. 7 Tips Aplikasi PAKEM. Jogjakarta: DIVA Press

Dewi, E P. 2008. Pengaruh Penerapan Model Pembelajaran Creative Problem Solving (CPS) dalam Pembelajaran Matematika terhadap Kemampuan Penalaran Adaptif Matematika Siswa SMA. Skripsi. FPMIPA UPI. Bandung.

Djalal, M.F. 1986. Penilaian Dalam Bahasa Asing. Malang: P3T IKIP Malang.

Hamalik, O. 1994. Kurikulum dan Pembelajaran. Jakarta: Bumi Aksara.

Nurman, M. 2006. Pengaruh Penggunaan Metode Pembelajaran Problem Based Learning dan Expositori terhadap Sikap Politik Berdemokrasi dan Prestasi Belajar Siswa pada Pembelajaran PPKn di SMP. Tesis. Program Pascasarjana, Institut Keguruan dan Ilmu Pendidikan Negeri. Singaraja.

Pasaribu, I.L. dan Simandjuntak, B. 1983. Metode Belajar dan Kesulitan Belajar. Bandung: Tarsito. 
Rahman, B. 2009. Perbandingan Kemampuan Koneksi Matematik Siswa yang Pembelajarannya Menggunakan Model Creative Problem Solving (CPS) dengan Siswa yang Pembelajarannya Menggunakan Model Konvensional. Skripsi. FPMIPA UPI. Bandung.

Sanan, S. J. dan Martinis, Y. 2013. Panduan Pendidikan Anak Usia Dini PAUD. Jakarta: Gaung Persada Press.

Sardiman, A.M. 1988. Interaksi dan Motivasi Belajar-Mengajar Pedoman bagi Guru dan Calon Guru. Jakarta: Rajawali Pers.

Sudjana, N. 1991. Dasar-Dasar Proses Belajar Mengajar. Bandung: Sinar Baru.

Sujiono, Y. N. 2009. Konsep Dasar Pendidikan Anak Usia Dini. Jakarta : Indeks.

Sulistyo, A. 2011. Panduan Mengajar dan Mendidik Anak Usia Dini. Depok: Millenia Pustaka.

Winkel, W.S. 1987. Bimbingan dan Konseling di Institusi Pendidikan. Jakarta: Gramedia. 